\title{
PUBLIC-PRIVATE PARTNERSHIP DEVELOPMENT IN SOUTHEAST ASIA
}

Fauziah Zen

NO. 553

August 2018
ADB ECONOMICS WORKING PAPER SERIES 
ADB Economics Working Paper Series

\section{Public-Private Partnership Development in Southeast Asia}

Fauziah Zen

No. 553 | August 2018
Fauziah Zen (fauziah.zen@eria.org) is a Senior Economist in the Economic Research Institute for ASEAN and East Asia.

This paper has been prepared as background material for the Asian Development Outlook 2017 Update theme chapter on Sustaining Development through Public-

Private Partnership. 
(C) 2018 Asian Development Bank

6 ADB Avenue, Mandaluyong City, 1550 Metro Manila, Philippines

Tel +632632 4444; Fax +6326362444

www.adb.org

Some rights reserved. Published in 2018.

ISSN 2313-6537 (print), 2313-6545 (electronic)

Publication Stock No. WPS189496-2

DOI: http://dx.doi.org/10.22617/WPS189496-2

The views expressed in this publication are those of the authors and do not necessarily reflect the views and policies of the Asian Development Bank (ADB) or its Board of Governors or the governments they represent.

ADB does not guarantee the accuracy of the data included in this publication and accepts no responsibility for any consequence of their use. The mention of specific companies or products of manufacturers does not imply that they are endorsed or recommended by ADB in preference to others of a similar nature that are not mentioned.

By making any designation of or reference to a particular territory or geographic area, or by using the term "country" in this document, $A D B$ does not intend to make any judgments as to the legal or other status of any territory or area.

This work is available under the Creative Commons Attribution 3.0 IGO license (CC BY 3.0 IGO)

https://creativecommons.org/licenses/by/3.o/igo/. By using the content of this publication, you agree to be bound by the terms of this license. For attribution, translations, adaptations, and permissions, please read the provisions and terms of use at https://www.adb.org/terms-use\#openaccess.

This CC license does not apply to non-ADB copyright materials in this publication. If the material is attributed to another source, please contact the copyright owner or publisher of that source for permission to reproduce it. $\mathrm{ADB}$ cannot be held liable for any claims that arise as a result of your use of the material.

Please contact pubsmarketing@adb.org if you have questions or comments with respect to content, or if you wish to obtain copyright permission for your intended use that does not fall within these terms, or for permission to use the ADB logo.

Notes:

In this publication, “\$” refers to United States dollars.

Corrigenda to ADB publications may be found at http://www.adb.org/publications/corrigenda. 


\section{CONTENTS}

TABLES AND FIGURES

ABSTRACT V v

$\begin{array}{ll}\text { I. INTRODUCTION } & 1\end{array}$

A. Infrastructure Development in Southeast Asia 1

B. Institutionalizing Public-Private Partnership 4

II. REGULATORY FRAMEWORK AND INSTITUTIONS IN SELECTED 5 SOUTHEAST ASIAN ECONOMIES

A. $\quad$ Infrastructure Industry in Southeast Asia 6

B. Closing Southeast Asia's Infrastructure Gap 8

III. APPROACHES TO PUBLIC-PRIVATE PARTNERSHIPIN SOUTHEAST ASIA

A. $\quad$ Risk Management and Support $\quad 14$

B. Public-Private Partnership Compared with Other Funding Options 14

C. Public-Private Partnerships to Support Master Plan of ASEAN Connectivity $2025 \quad 14$

IV. POTENTIALS OF PUBLIC-PRIVATE PARTNERSHIP FOR SOCIAL INFRASTRUCTURE 15

V. PRO-POOR PUBLIC-PRIVATE PARTNERSHIP 16

A. Opportunities and Challenges 18

B. Case Studies: Umbulan Water Supply System Project in East Java, Indonesia 19

$\begin{array}{lll}\text { VI. } & \text { RECOMMENDATIONS } & 21\end{array}$

$\begin{array}{lc}\text { REFERENCES } & 23\end{array}$ 


\section{TABLES AND FIGURES}

\section{TABLES}

$1 \quad$ Public-Private Partnership and General Government Gross Fixed Capital Formation in Five Southeast Asian Countries, 2005-2015

2 Infrastructure Priority and Financing Needs 9

3 Transactions Included in Public-Private Partnership Policy 12

4 The Global Competitiveness Index 2017-2018 Rankings for Southeast Asian Countries 13

\section{FIGURES}

$1 \quad$ Infrastructure and Institutions Scores in Southeast Asia and Selected Developed 2

Economies, 2017-2018

2 Infrastructure "Ecosystem" $\quad 7$

3 Infrastructure Stock in Indonesia, 1995-2015 8

$4 \quad$ Fundamental Infrastructures for Empowering People 16

5 Umbulan Spring Project Transaction Scheme 20 


\begin{abstract}
Infrastructure development in Southeast Asia has been financed mainly by public funds, which leave wide gaps in majority of countries. Governments have tried to attract the private sector by offering various schemes under public-private partnership (PPP). Typically, PPP contributes less than $1 \%$ of gross domestic product, while public finance greatly varies from about $2 \%$ to $10 \%$ of a country's gross domestic product. Among major factors supporting PPP implementation, the following features are critical: coherent policy, public sector capacity to manage PPP appropriately, public sector willingness to have mutual relation with private partners, and leadership. Private participation is still continuously growing; and its implementation is not limited to hard infrastructure only, but also to social infrastructure.
\end{abstract}

Keywords: infrastructure development, private sector participation, public-private partnership, social infrastructures

JEL codes: $\mathrm{H} 54, \mathrm{O} 21, \mathrm{R} 53$ 


\section{INTRODUCTION}

Infrastructure is fundamental to support economic growth and human well-being. It provides goods and services for direct use as well as supports other socioeconomic activities. Using a sample of advanced economies, the International Monetary Fund estimates that an increase of $1 \%$ in investment spending raises gross domestic product (GDP) by approximately $0.4 \%$ in the same year and by $1.5 \%$ in 4 years after the increase (IMF 2014). Lee et al. (2018) projected that doubling PPP investment from 0.5\% of GDP in 2015 to $1 \%$ generate additional 0.1 percentage points to GDP growth per capita across Asia and the Pacific. Perhaps the most challenging issue in infrastructure development is the financing of construction or funding the operation and maintenance. Since many infrastructure projects are categorized as noncommercial, it becomes the responsibility of the public sector.

Since public funds are limited, infrastructure development competes with other spending priorities, hence, shortage of its supply. Government partners with the private sector to fill this gap. The public-private partnership (PPP) allows the private sector to utilize its competence and innovative resources; and, at the same time, to gain fair benefits from it. Users receive higher benefits and better quality services resulting from private sectors' professionalism and efficiency.

The challenges to apply PPP in a large scale is that it is a complex system; requires specific and sufficient knowledge of financing structure, risks allocation, contract management, and disputes resolution; and the transaction process usually takes a long time to conclude. Hence, the capacity of the public sector is crucial and it still needs resources and funds from the public side. This paper attempts to provide the landscape of infrastructure development in majority of the Association of Southeast Asian Nations (ASEAN) member states with emphasis on financing mechanism, in which PPP is promoted as strong complement of limited public funds. It also discusses the "infrastructure ecosystem," and the potential to use PPP in social infrastructure and pro-poor development planning.

\section{A. Infrastructure Development in Southeast Asia}

Infrastructure development in Southeast Asia is at different stages depending on each country's governing policy on PPP. Singapore has the most developed infrastructure in the region, which is on par or even better than many advanced economies. As a compact and island city-state focusing on the service sector, Singapore has been carefully building facilities to support its specific constraints and demands. In particular, its transportation system is well developed and connected and energy provision is safely secured.

The Global Competitiveness Report 2017-2018 by the World Economic Forum (WEF) has consistently ranked Singapore second in global competitiveness index since 2012. Closely related to effective infrastructure implementation is institutional environment which the WEF defines as influential factors to "investment decisions and the organization of production and plays a key role in the ways in which societies distribute the benefits and bear the costs of development strategies and policies." Further, because PPP requires a supportive business environment that underpins investment decisions, it is also important to consider the macroeconomic conditions of Southeast Asian countries. As expected, both infrastructure and institutions pillars show close scores (Figure 1). 


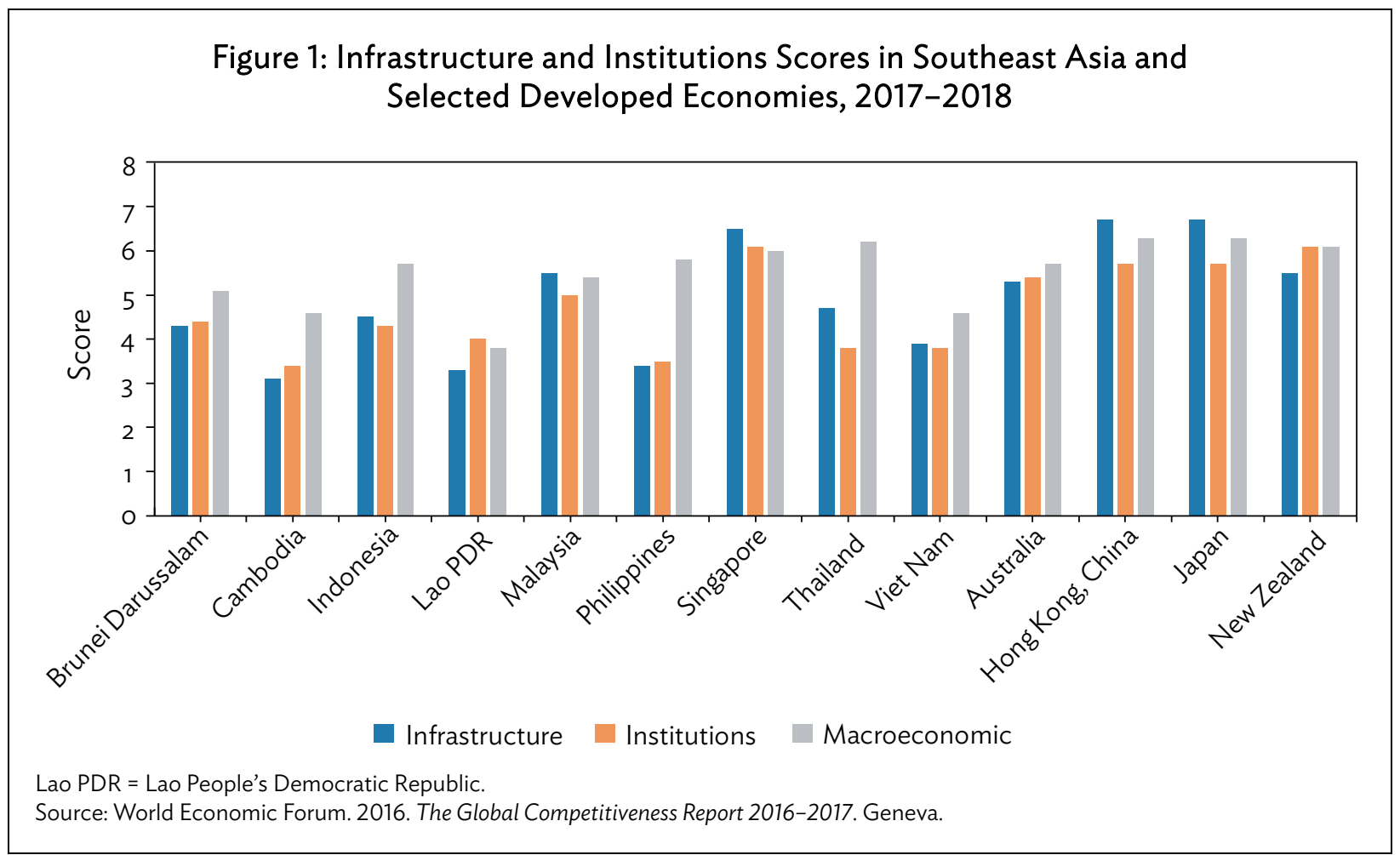

Figure 1 indicates a consistent pattern of close linkages between fundamental macroeconomic and institutional variables, and infrastructure development. Intuitively, infrastructure is needed to foster growth and macroeconomic stability, while good business climate, represented by positive macroeconomic and supportive institutional frameworks, will attract more investments, including in infrastructure.

Infrastructure development in Cambodia, the Lao People's Democratic Republic (Lao PDR), Malaysia, and the Philippines lags far behind the average of selected developed economies. Since PPP is still in the early stage of policy maturity in these countries, large portions of their infrastructure finances come from public funds, including loans, and in smaller portion, from privatization.

Indonesia has invested much in fixed assets (capital formation). Even though not all fixed assets are in the form of infrastructure, the numbers can be used as a proxy for infrastructure investment. According to Indonesia's national development plan, it needs $\$ 409$ billion to finance major infrastructure investments for the period 2015-2019. The projects include 15 new airports, 24 seaports, 2,650 kilometers $(\mathrm{km})$ of road, $3,258 \mathrm{~km}$ of railway track, and bus rapid transit development in 29 cities. It requires about $\$ 82$ billion for infrastructure investment per annum or approximately $9 \%-10 \%$ of its nominal GDP over 5 years. State-owned enterprises (SOEs) and the private sector are expected to fund $59 \%$ of infrastructure investment requirements.

PPP has been playing an increasing role in Southeast Asia at different rates. In countries where public funds are abundant or public institutions are very strong, such as Brunei Darussalam and Singapore, PPP plays fewer roles in infrastructure development. Strong calls for PPP have been promoted, especially in Indonesia, Malaysia, the Philippines, Thailand, and Viet Nam. However, public sector commitment for PPP and the realization of planned PPP projects are not always in the same path with the ambitious calls. 
Since the call for PPPs during the Indonesia Infrastructure Summit 2005 and the subsequent yearly announcement of the Government of Indonesia of its project pipeline, there has been progress in the country's PPP regulatory framework. However, this progress has not been followed by an increase in the number of realized projects. Until 2015, the first national PPP project under the reformed PPP framework in 2006 was only the independent power producer project in Batang, Central Java. This project's financial closing has been delayed since it was awarded in 2011 because of a land acquisition problem, and it was just concluded at the end of 2016. The other PPP projects that have reached financial closing recently are Palapa Ring backbone network project and Umbulan Bulk Water Supply project in East Java. Other potential projects are still in the bidding or negotiation stage.

The Philippines PPP Center has been more progressive. It has awarded 16 PPP contracts worth approximately $\$ 6.4$ billion since 2010. Completed projects include the Ninoy Aquino International Airport Expressway and 12,202 classrooms in six regions, while the Mactan-Cebu International Airport New Passenger Terminal Building and the Bulacan Bulk Water Supply Project are both under construction.

In Thailand, there are 44 PPP projects run by 16 agencies based on the State Enterprise Policy Office report. They cover transportation and logistics, utilities, telecommunication, and property development. The State Enterprise Policy Office also released the PPP Master Plan 2015-2019 to determine the direction for sectors and types of commercial and social investments with private participation.

In general, the role of PPP financing in Southeast Asia is still minor. A significant portion of its infrastructure finance comes from public funds. In five main countries promoting PPP (Indonesia, Malaysia, the Philippines, Thailand, and Viet Nam), PPP typically contributes only less than $1 \%$ of GDP, while public finance greatly varies from about $2 \%-10 \%$ of a country's GDP (Table 1 ).

\section{Table 1: Public-Private Partnership and General Government Gross Fixed Capital Formation in Five Southeast Asian Countries, 2005-2015 (\% of GDP)}

\begin{tabular}{|l|l|l|l|l|l|l|l|l|l|l|}
\hline \multirow{2}{*}{ Year } & \multicolumn{2}{|c|}{ Indonesia } & \multicolumn{2}{c|}{ Malaysia } & \multicolumn{2}{c|}{ Philippines } & \multicolumn{2}{c|}{ Thailand } & \multicolumn{2}{c|}{ Viet Nam } \\
\cline { 2 - 11 } & PPP & GFCF & PPP & GFCF & PPP & GFCF & PPP & GFCF & PPP & GFCF \\
\hline 2005 & 0.08 & 3.05 & 1.48 & 9.40 & 0.32 & 1.82 & 0.43 & 6.24 & 0.56 & 5.59 \\
2006 & 0.11 & 3.91 & 1.11 & 9.56 & 0.17 & 1.69 & 0.31 & 6.15 & 0.48 & 5.30 \\
2007 & 0.15 & 3.42 & 0.98 & 9.54 & 0.14 & 2.07 & 0.27 & 6.30 & 0.19 & 6.03 \\
2008 & 0.22 & 2.99 & 0.59 & 9.64 & 0.12 & 2.42 & 0.28 & 5.82 & 0.17 & 5.99 \\
2009 & 0.18 & 2.80 & 0.37 & 10.08 & 0.47 & 2.88 & 0.30 & 6.11 & 0.22 & 8.51 \\
2010 & 0.19 & 2.50 & 0.14 & 9.81 & 0.61 & 2.87 & 0.18 & 5.55 & 0.33 & 8.09 \\
2011 & 0.15 & 2.85 & 0.07 & 9.53 & 0.61 & 1.84 & 0.22 & 5.00 & 0.61 & 6.76 \\
2012 & 0.20 & 3.16 & 0.19 & 10.50 & 0.64 & 2.84 & 0.29 & 5.08 & 0.56 & 7.60 \\
2013 & 0.19 & 3.54 & 0.26 & 10.21 & 0.65 & 2.58 & 0.26 & 5.05 & 0.49 & 7.72 \\
2014 & 0.22 & 2.96 & 0.24 & 9.16 & 0.40 & 2.63 & 0.42 & 4.58 & 0.58 & 6.56 \\
2015 & 0.19 & 3.36 & 0.21 & 8.81 & 0.50 & 3.08 & 0.31 & 5.78 & 0.48 & 6.38 \\
\hline
\end{tabular}

$\mathrm{GDP}=$ gross domestic product, $\mathrm{PPP}=$ public-private partnership.

Source: IMF, Investment and Capital Stock Dataset. 2017. The Accompanying 2017 Update of the Manual "Estimating Public, Private, and PPP Capital Stocks." http://www.imf.org/external/np/fad/publicinvestment/data/info122216.pdf and http://www.imf.org/external/pp/longres.aspx?id=4959 (accessed 30 September 2017). 
Malaysia, Viet Nam, and Thailand have been consistently spending a great amount of their state budgets on infrastructure development. Indonesia has recently been investing a large amount of its budget on infrastructure but, in terms of GDP percentage, it is still considerably low. Moreover, its demand for infrastructure varies with the existing stock, growth, and geographical challenges. As the largest archipelagic country, Indonesia faces challenges in interisland connectivity and the concentration of the population in Java Island, which makes places outside Java and Sumatra with less economies of scale.

Comparing the figures in Table 1 should be done cautiously as there are different terms used to represent PPP spending or infrastructure spending by governments. Different nomenclatures are normal; some are influenced by different structures of government systems. For example, government spending may or may not represent both national and subnational expenditures of governments. Another source of difference is how the country defines PPP. Malaysia, for instance, includes privatization in its definition of PPP, while in other countries it is excluded.

\section{B. Institutionalizing Public-Private Partnership}

PPPs are handled in various ways in Southeast Asia. Some countries define PPP terms, and set up dedicated units to deal with its implementation. Others institute PPP as part of a larger investment or public institution. Malaysia established Unit Kerjasama Awam Swasta (UKAS) as part of its transformation from its privatization program in the early 1980s. The Philippines set up the PPP Center that acts as a one-stop service to handle PPP processes. Thailand set up the PPP Unit. Viet Nam established the PPP Office under the Ministry of Planning and Investment as a one-stop shop division in charge of national coordination of PPP projects.

Indonesia has more than one institution responsible for its PPP programs, consisting of the National Development Planning Agency (Badan Perencanaan Pembangunan Nasional - BAPPENAS), the Ministry of Finance, and line ministries. They are coordinated by the Coordinating Minister for Economic Affairs. To speed up the implementation of prioritized infrastructure projects, President Joko Widodo established the Policy Committee for the Acceleration of Infrastructure Provision (Komite Kebijakan Percepatan Penyediaan Infrastruktur - KPPIP) in 2014 to set the national priority project list and coordinate its implementation.

Having several agencies responsible for PPP potentially leads to an overlap of authority and a prolonged process. To add more complexities, the country embraces decentralization at the second level of subnational government. This adds more stakeholders, permits, and license requirements, and results in longer processes for negotiations and fulfilling the requirements.

In brief, PPP policy in Southeast Asia has different stages and rates of implementation. It is difficult to make a straightforward comparison because of the difference in terms and definitions, expenditure classifications, and country government systems. However, common success factors and obstacles may be attributed to specific features of the system. Among the major factors supporting PPP implementation, the following features are critical: coherent policy, public officers with sufficient PPP knowledge, public sector willingness to have mutual relationships with private partners, and leadership. 
The PPP policy framework also differs from one country to another, influenced largely by internal variables such as governance system, fiscal capacity, institutional framework, judicial system, and financial market. But there is no evidence that a particular system is superior to another. It does not matter whether a country has a special PPP law or it is embedded in other laws, as long as it enables a PPP environment. The critical point is having coherent policies for investment in general and for PPP, and inefficiencies in time and budget are avoided and eliminated. Incoherent policy will confuse investors, create additional burdens, and prolong the process. In the end, it will reduce investors' confidence and government's credibility. Changing regulations or discriminative regulations, as well as redundant processes for licenses demanded by various public agencies, are among major complaints from investors.

Public sector capacity is another vital requirement that should be in place considering that PPP is more complex and demands specific knowledge. The WEF's survey finds public sector capacity among the top challenges for doing business in many emerging countries. The components of PPP need to be understood comprehensively by the public sector before it can apply some innovations and introduce some adjustments and flexibilities without jeopardizing the economy. In many cases, the government treats PPP similarly as traditional procurement systems, resulting in incompatible restrictions and eliminating the advantages of PPP. This typically leads to risk-averse behavior in public agencies that would likely shift all risks to private partners. In Indonesia, because of the inability to handle the complexity, several intended PPP projects have been diverted into traditional public procurements or assigned to SOEs.

The willingness to have mutual relationships with private partners and leadership from relevant government agencies is a necessary condition to have a workable PPP development program. The relationship must have the capacity to offer the same level of understanding and bargaining during the process of risk and support negotiations. In parallel, leadership should provide relevant agencies with sufficient power to authorize, lead the process, and decide on timely solutions in critical situations. The lead agency should be the champion of PPP. The authority given to this agency should be at a sufficient level to be obeyed by stakeholders. The PPP Center in the Philippines has full support from the country's President and can effectively approach crosscutting sectors.

In addition, major surveys on transparency index in emerging Southeast Asian economies usually put corruption as one of the most problematic challenges in doing business. When corruption practices are rampant, they will affect the whole PPP process in many ways, including reducing efficiency and driving out good investors from the playing field. Hence, it is very important for governments to improve fundamental factors underpinning good investment climate.

\section{REGULATORY FRAMEWORK AND INSTITUTIONS IN SELECTED SOUTHEAST ASIAN ECONOMIES}

The institutional and legal frameworks for PPPs are heavily influenced by the fact that governments lead these partnerships. Legal frameworks define the rules for and the role of public sector and private entities participating in PPPs. The government agencies responsible for the process of implementing PPPs determine the efficiency and effectiveness of these rules. A poor performance will not only affect the direct costs for private entities participating in a PPP but also indirect and intangible costs, such as investor confidence and risk perceptions.

Research by Ismail and Haris (2014) on the possible constraints that hinder the implementation of PPP in Malaysia shows that the obstacles are lengthy delays in negotiation, lack of government 
guidelines and procedures on PPP, higher charges to direct users, lengthy delays because of political debate, and confusion over government objectives and evaluation criteria. In addition, unsolicited proposals are not regulated within the PPP framework. Meanwhile, the most critical area of PPP in Malaysia is value for money (VFM) (Ismail 2012).

Indonesia has been reforming its PPP-related legal aspects to speed up the process. During the last 5 years, there have been revised regulations on the scope of PPP, land acquisition, and government support (i.e., guarantee and availability payment). Some improvements were made, including the progress of three projects that reached financial closing in late 2016, and another four projects (all toll roads) that are currently on the stages of bidding and negotiation. However, the progress of implementation is slow, usually because of inconsistent actions by public agencies.

Thailand, in the early 1990s, initially used a PPP approach to eliminate corruption practices in project procurement and protect public interests. In 2013, it enacted the Private Investment in State Undertaking Act, with additional provisions to promote PPP investment. The standards have been set through institutionalizing the PPP Master Plan, PPP Committee, and PPP Unit; and through a set of guidelines for VFM, small projects, and the PPP database. It also facilitates streamlined procedure and determined timeline, and provides project development funds.

The Philippines has several strong points in its PPP programs, especially in leadership of PPP; clear guidelines on cost-benefit analysis (CBA), risk assessment, and comparative modality; and clear references to structure the schemes. Progressive PPP development in the Philippines cannot be detached from the strong commitment and massive PPP education of relevant officials (especially local governments) and the public in general. Familiarity to the concept is important to gain public support, eliminate unnecessary public disputes, and promote transparency.

\section{A. Infrastructure Industry in Southeast Asia}

"Infrastructure ecosystem" is a system which links the three components namely management, construction, and financing with one another (Figure 2). Infrastructure is a unique industry. Its demand is typically generated by the public sector, making the government a key actor in this industry. On the management part, the owner is usually the public sector, while the users may be the public at large or specific users; for example, industrial zones.

Building of infrastructure projects is done by construction companies that typically consist of two large groups: project developer and contractor, and mechanical and electrical systems. In many developing economies, they can be both private companies and SOEs.

Financing infrastructure is typically considered the most challenging part in emerging economies. Apart from fully privatized projects, PPP requires contributions from both the public and private sectors. Public finance can offer several mechanisms and schemes to support PPP projects such as Viability Gap Funding (VGF), land provision, tax allowance, revenue guarantee, and loan guarantee. To avoid breaching good governance principles, they are determined by regulations and are typically benchmarked to international standards. On the other hand, the private fund has a straight rule that is financial profit. 
Figure 2: Infrastructure “Ecosystem"

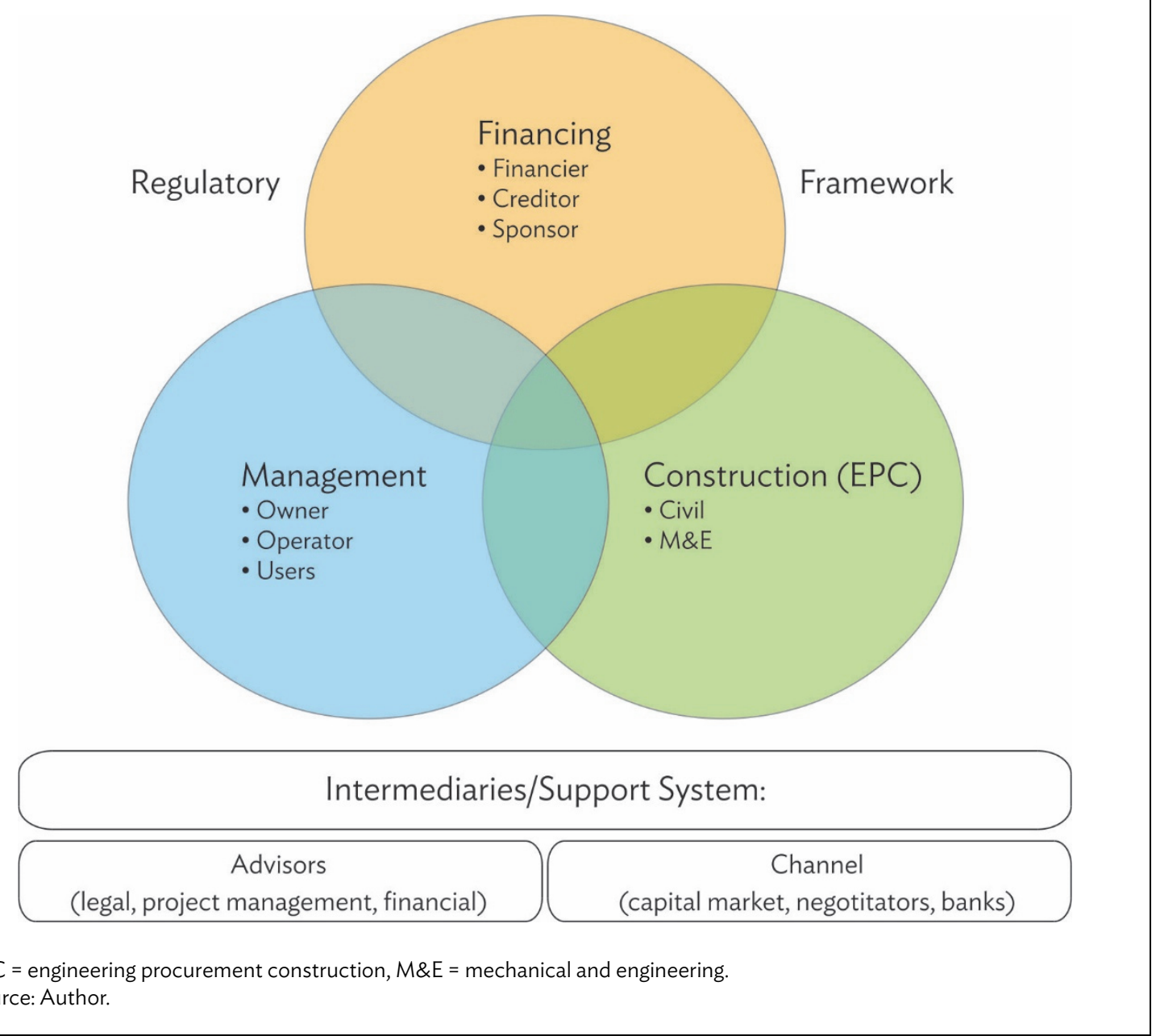

The size and completeness of the infrastructure industry influence the level of competitiveness, attractiveness, and potential growth. They can also be used as proxy for efficiency and institutional excellence. Fewer players in the industry means limited choices, limited access, higher hiring costs, and perhaps few bankable projects.

For PPP projects that are financially feasible, the government in general reduces fiscal support and focuses on nonfiscal aspects to push the project. For instance, it will eliminate the regulatory burden, streamline the process, or set up optimal risks allocation. Meanwhile, if the project is not financially feasible but economically viable, the private party will demand larger support from public agencies in order to make the project sustainable and produce fair returns.

Apart from exploring possible schemes and financial engineering, PPP offers advantages of fostering healthy competition, innovation, and improving public sector efficiency. While it may be difficult to expect great innovation in technology or financial engineering occurring in emerging economies given the short history of PPP in infrastructure, schemes such as design, renovate, and maintain can offer opportunities to enhance efficiency and embrace innovation in public services 
delivery by utilizing private sector competencies. Expecting greater innovation from the private sector consequently requires higher capacity of the public sector to deal with flexibilities and maintain the substances at the same time.

\section{B. Closing Southeast Asia's Infrastructure Gap}

Countries across Southeast Asia are increasing their efforts to narrow their infrastructure gaps. This section looks at the recent infrastructure programs of four countries: Indonesia, Malaysia, the Philippines, and Thailand.

\section{Indonesia}

Since the Asian financial crisis in 1997, Indonesia's spending on infrastructure has been lower than its precrisis spending, leading to stagnant and decreasing stock per GDP (Figure 3). A small infrastructure budget means insignificant spending for building new projects, and even lower allocation for maintaining the existing infrastructure. This situation, combined with ineffective prioritization policy, has hampered Indonesia's growth opportunity. For a decade, Indonesia's infrastructure supply had been short of its demand, resulting in road congestions in urban areas, high logistic costs, almost no new infrastructure built outside Java Island, electricity blackout, and many more.

Figure 3: Infrastructure Stock in Indonesia, 1995-2015

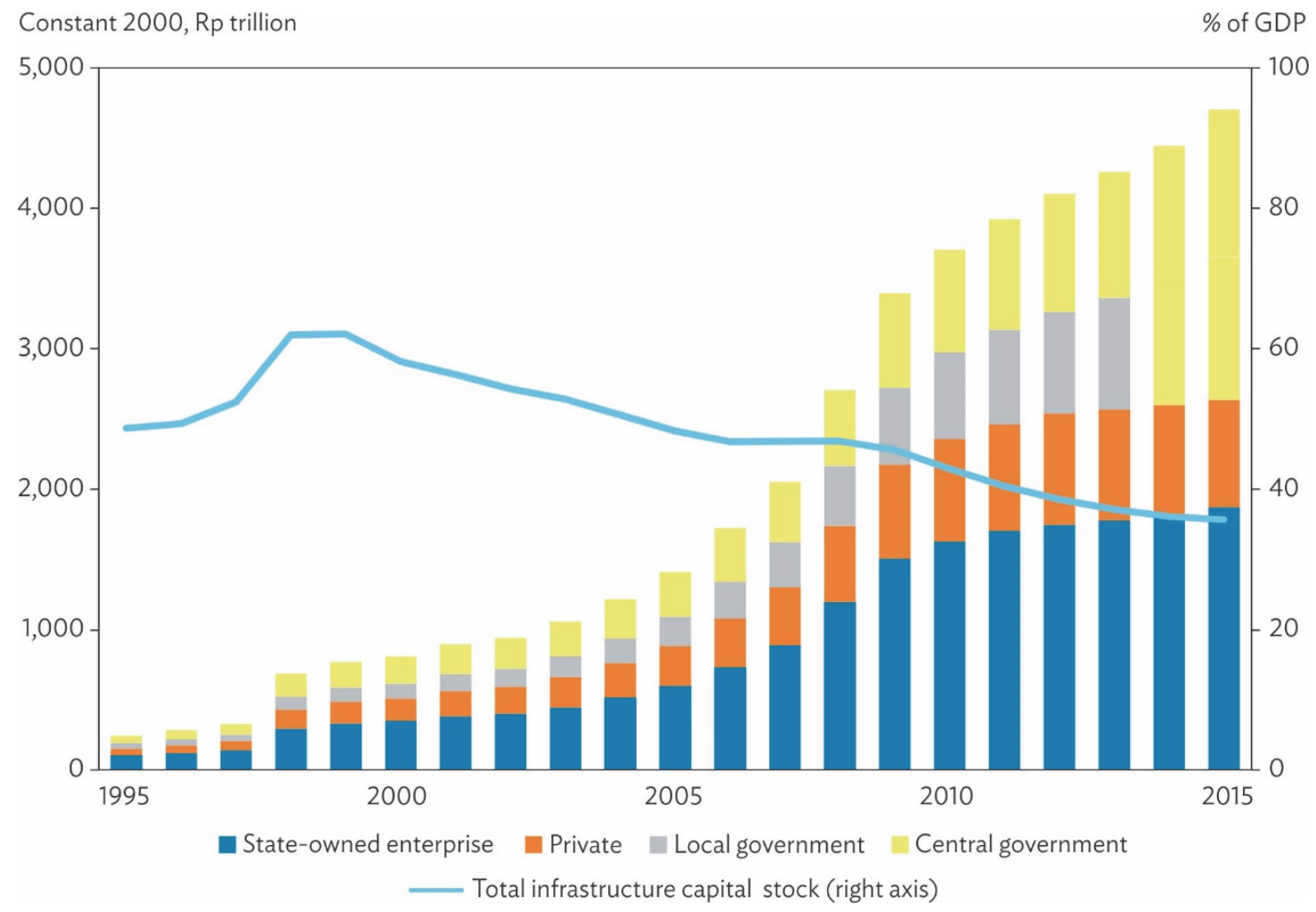

$\mathrm{GDP}=$ gross domestic product, $\mathrm{Rp}=$ rupiah

Note: Capital stock estimated using the perpetual inventory method, assuming $5 \%$ depreciation rate.

Source: Australia Indonesia Partnership for Economic Governance (AIPEG). http://www.aipeg.or.id/. 
President Joko Widodo, who took the position in October 2014, has a different economic policy from his predecessor. He believes that infrastructure plays a significant role in economic development and he has committed to develop outside Java. During his first years of presidency, he lifted energy subsidy but allocated significant funds for universal health care, education, and infrastructure. BAPPENAS estimated three scenarios for infrastructure development (Table 2) and expected that approximately $60 \%$ of the funds come from SOEs and PPPs.

Table 2: Infrastructure Priority and Financing Needs (Rp billion)

\begin{tabular}{|c|c|c|c|c|}
\hline 2015-2019 Infrastructure Plan & $\begin{array}{l}\text { Infrastructure Financing Needs } \\
\qquad 2015-2019\end{array}$ & $\begin{array}{c}\text { Scenario } \\
1 \text { (full } \\
\text { scenario) }\end{array}$ & $\begin{array}{l}\text { Scenario } \\
2 \text { (partial } \\
\text { scenario) }\end{array}$ & $\begin{array}{l}\text { Baseline } \\
\text { Scenario }\end{array}$ \\
\hline New roads $-2,650 \mathrm{~km}$ & Roads & 1,274 & 851 & 637 \\
\hline Highway - 1,000 km & Rail system & 278 & 222 & 140 \\
\hline Road maintenance - 46,770 km & Urban transportation & 155 & 115 & 75 \\
\hline Bus corridors - 2 & Sea transportation & 563 & 424 & 282 \\
\hline New seaports - 24 & Ferry and other water transportation & 91 & 80 & 60 \\
\hline Seaport development - 59 & Air transportation & 182 & 165 & 100 \\
\hline Pioneer cargo ships - 26 & Electricity & 1,080 & 762 & 714 \\
\hline New airports - 15 & Energy and gas & 535 & 420 & 268 \\
\hline Airport infrastructure development & Water resources & 1,091 & 845 & 645 \\
\hline Airplanes - 20 & Water and sanitation & 666 & 450 & 330 \\
\hline Rail lines - 2,159 km & Public housing & 384 & 247 & 180 \\
\hline \multirow[t]{2}{*}{ Intracity rail lines - 1,099 km } & Information and communication technology & 242 & 200 & 130 \\
\hline & Total & 6,541 & 4,781 & 3,561 \\
\hline
\end{tabular}

$\mathrm{km}=$ kilometer, $\mathrm{Rp}=$ rupiah .

Note: State-owned enterprises and public-private partnership are expected to fill the funding gap since central government can only fulfil about $20 \%$ of the needs.

Sources: Ministry of Finance, Republic of Indonesia. 2016. "State Budget FY 2016" (in Bahasa Indonesia) and National Development Agency. 2014. "2015-2019 National Development Agenda” (in Bahasa Indonesia).

As infrastructure development was an important part of President Widodo's campaign, he instructed the acceleration of infrastructure projects. While PPP requires longer time due to its complexities, several projects that were initially declared as PPPs were assigned to SOEs. Recently, several abandoned backbone projects have been completed or nearly completed in the islands of Kalimantan, Sulawesi, Sumatra, and Papua. There is additional fund in the form of special transfer to subnational governments to support local infrastructure development. On the other hand, sovereign debt increased, but it is still manageable at below $27 \%$ of GDP.

\section{Philippines}

Under President Rodrigo Duterte's administration, the Philippines launched a 10-Point Socioeconomic Agenda that includes accelerated infrastructure spending, of which PPP plays a key role. The focus of the programs is on transportation, new master plans of cities, and digital infrastructure (internet speed and coverage). Among the key policies are:

(i) Increased public infrastructure to $7 \%$ of GDP:

(a) Luzon 2045 infrastructure amounted to PHP8.1 trillion;

(b) Visayas 2045 infrastructure amounted to PHP 4.4 trillion; 
(c) Mindanao 2045 infrastructure amounted to PHP6 trillion; and

(d) PPP pipeline amounted to PHP5.9 trillion.

(ii) Ease in approvals of project proposals:

(a) fight against red tape;

(b) PHP5 billion below - no need for Investment Coordination Committee and National Economic and Development Authority approval;

(c) social discount rate lowered from $15 \%$ to $10 \%$; and

(d) increase capacity of regional development councils and local government units with funds on feasibility study and detailed engineering preparation.

The current administration focuses on building infrastructures at a massive rate, creating millions of jobs, and lowering prices of commodities. The National Economic and Development Agency, the Department of Transportation, the Department of Public Works and Highways, and the Bases Conversion and Development Authority are responsible for implementing the Duterte Infrastructure Plan. The Philippines expects an increase of infrastructure spending during 2017 (Investor Relations Office 2017).

\section{Malaysia}

Malaysia's infrastructure development program is part of its 5-year medium-term national development plan, the 10th Malaysia Plan. This plan started in 2011 until 2015 and was succeeded by the 11th Malaysia Plan for 2016-2020 (Government of Malaysia, Prime Minister's Department 2015).

The 11th Malaysia Plan 2016-2020: Anchoring Growth on People was prepared by the Economic Planning Unit of the Prime Minister's Department in 2016. The plan has five strategic thrusts, namely:

(i) enhancing inclusiveness toward an equitable society,

(ii) improving well-being for all,

(iii) accelerating human capital development for an advanced nation,

(iv) pursuing green growth for sustainability and resilience, and

(v) reengineering economic growth for greater prosperity.

The five strategic thrusts focus on strengthening infrastructure to support economic expansion, which consists of:

(i) building an integrated need-based transport system;

(ii) unleashing growth of logistics and enhancing trade facilitation;

(iii) improving coverage, quality, and affordability of digital infrastructure;

(iv) continuing the transition to a new water services industry framework; and

(v) encouraging sustainable energy use to support growth.

The government expects that Malaysia's planned mega infrastructure projects will move the country's economy into RM2 trillion ( $\$ 505$ billion) by around 2025 . The projects include the KL-Singapore High Speed Rail link, the Pan Borneo Highway, East Coast Rail Link', Bandar Malaysia², and

1 The East Coast Rail Link will connect Port Klang and Kuala Lumpur (in west coast) to Pahang, Trengganu, and Kelantan in the central and east coast of Peninsular Malaysia.

2 Bandar Malaysia is an urban redevelopment project, located near the airport in Sungai Besi and will incorporate Kuala Lumpur-Singapore high-speed rail. 
Vision Valley. The government provides tax incentives to attract RM6.5 billion ( $\$ 1.5$ billion) in investments and create 14,000 jobs.

\section{Thailand}

Thailand announced its Transport Infrastructure Development Master Plan 2015-2022 in 2015 with a total investment of B1,913 billion. The objectives of the master plan are to strengthen social and economic security, increase transport safety, improve the quality of life, and enhance competitiveness and gain potential benefits from the ASEAN Economic Community (Nitithanprapas 2016).

The plan includes several big projects, namely:

(i) upgrading rail and its facilities, and building a double-track railway network and its extension to the border;

(ii) constructing four-lane road networks connecting growth centers with border areas;

(iii) extending the metro rail transit, procuring new buses, and improving quality of roads and bridges in Bangkok;

(iv) developing a multimodal transport system and cross-border logistics center;

(v) developing seaports on Thai gulf and Andaman Sea; and

(vi) increasing airport capacity and improving airport-related services.

Apart from the master plan, Thailand has an annual investment action plan (IAP) which started in 2015. IAP 2015 comprises 59 projects with an investment cost of B848 billion. Of this, B56 billion is expected to be disbursed in 2015 and the rest would be carried over during the next 7-year period from 2016 to 2022. IAP 2016 was planned with 20 projects worth B1.8 trillion. By the end of 2016, the Ministry of Transport announced that seven projects with a total investment of B874 billion were postponed.

\section{APPROACHES TO PUBLIC-PRIVATE PARTNERSHIPS IN SOUTHEAST ASIA}

Infrastructure investments are typically large, with stable but modest returns. When investors deal with governments of emerging countries with less mature PPP policy, they face higher risks of changing regulations or being guided by unclear rules. Investors spend months and millions of money to secure a contract and yet the government may cancel or postpone the bidding process without proper reason. This leads to high sunk costs in many infrastructure projects. Therefore, contracts play a significant role despite the presence of specific PPP laws.

Apart from the public sector capacity challenge discussed in section I, the other challenge is less developed financial market. Emerging economies in Southeast Asia have yet to utilize potential funds that need capital market mechanisms to channel them. Large potential institutional investors, such as pension funds and insurance companies, have less access to diversify their portfolios into infrastructure projects in emerging economies. Enhancing capital markets in emerging economies requires long-term and consistent efforts, given its complexities and linkages to other economic sectors.

PPP terms have broad variations and definitions across the world. Emerging economies in Southeast Asia also use terms with different levels of implementation. As PPP can take various forms of approach, this paper defines it as long-term arrangements featuring private capital at risk and the allocation of transactional risk to the private party, including responsibility for life cycle costs (Zen and Regan 2015). The variations in implementation depend on the stage of PPP policy adopted by the country (Table 3 ). 
Table 3: Transactions Included in Public-Private Partnership Policy

\begin{tabular}{|c|c|c|c|}
\hline & $\begin{array}{l}\text { Early Stage or } \\
\text { Initial Stage } \\
\text { PPP Policy }\end{array}$ & $\begin{array}{l}\text { Intermediate } \\
\text { Stage } \\
\text { PPP Policy }\end{array}$ & $\begin{array}{l}\text { Mature Stage } \\
\text { PPP Policy }\end{array}$ \\
\hline Privatization of state businesses enterprises & $x$ & & \\
\hline Privatization of state assets & $x$ & & \\
\hline Privatization with residual interest & $x$ & & \\
\hline Private finance initiative & $x$ & $x$ & $x$ \\
\hline $\begin{array}{l}\text { Build-operate-transfer, build-own-operate, and } \\
\text { build-own-operate-transfer contracts }\end{array}$ & $x$ & $x$ & $x$ \\
\hline Design-renovate-build-operate contracts & $x$ & $x$ & $x$ \\
\hline Operation and maintenance contracts & $x$ & $x$ & $x$ \\
\hline Design-build-finance-operate contracts & $x$ & $x$ & $x$ \\
\hline Renovate-build-operate contracts & $x$ & $x$ & $x$ \\
\hline Concessions & $x$ & $x$ & $x$ \\
\hline Management and service contracts & $x$ & $x$ & \\
\hline Traditional construction contracts & & & \\
\hline
\end{tabular}

PPP = public-private partnership.

Source: Zen, Fauziah, and Michael Regan. 2015. Financing ASEAN Connectivity. Indonesia: Economic Research Institute for ASEAN and East Asia.

PPP in emerging Southeast Asia is less expected to bring great innovation or sophisticated financial engineering. However, it helps build the infrastructure and fill some of the gaps. What governments need to do is to set realistic expectations on their PPP targets, while pushing forward their system improvements and capacities.

Within this context, we can categorize the ASEAN member states into two general groups; namely, countries with progressive and more developed PPPs (Indonesia, Malaysia, the Philippines, Singapore, and Thailand), and countries with less developed PPPs (Brunei Darussalam, Cambodia, the Lao PDR, Myanmar, and Viet Nam). Both groups have their own challenges. In terms of infrastructure financing, there are four major factors that determine the attractiveness, options, and size of financing; namely

- Stage of economic development. This determines the types of available projects, economic demands, and the fiscal and knowledge capacity to carry out a project.

- Fiscal management. This determines the capacity to provide fiscal support, guarantees, cofunding, and securing loans for infrastructure financing.

- Capital market development. This determines the confidence level to invest in a project and the available financing channels, especially for long-term investors.

- Regulatory framework. This determines the ease of investing in a PPP, the level of secured investments, and cost efficiency.

Countries belonging to the progressive and more developed PPP group have similarities with these four factors. They typically have capacity to secure loans or cofund infrastructure projects, and grow demand for infrastructure projects, especially in urban areas. They have a mature fiscal management system that minimizes the potential to default and provides support for infrastructure 
projects. Their capital markets have been developed and some are already at a mature stage, allowing institutional investors to channel their long-term funds. The legal system in this group is generally complete, relatively clear, and predictable, with some variations across countries.

Typical challenges are to maintain and speed up the improvement efforts. This step could be complicated largely due to political economic factors. It requires strong leadership to make stakeholders consistently move forward.

\section{Table 4: The Global Competitiveness Index 2017-2018 Rankings for Southeast Asian Countries}

\begin{tabular}{|c|c|c|c|}
\hline Rank & Economy & Driver & Areas for Improvement \\
\hline 3 & Singapore & Innovation & None \\
\hline 23 & Malaysia & $\begin{array}{l}\text { Transition from efficiency- } \\
\text { driven to Innovation-driven }\end{array}$ & Higher education, innovation \\
\hline 32 & Thailand & Efficiency-driven & $\begin{array}{l}\text { Institutions, health, primary education, higher } \\
\text { education, labor market, and innovation }\end{array}$ \\
\hline 36 & Indonesia & Efficiency-driven & $\begin{array}{l}\text { Institutions, infrastructure, health, primary education, } \\
\text { higher education, market efficiency, and innovation }\end{array}$ \\
\hline 56 & Philippines & $\begin{array}{l}\text { Transition from factor-driven } \\
\text { to efficiency-driven }\end{array}$ & $\begin{array}{l}\text { Institutions, infrastructure, health, primary education, } \\
\text { higher education, market efficiency, and innovation }\end{array}$ \\
\hline 46 & Brunei Darussalam & $\begin{array}{l}\text { Transition from factor-driven } \\
\text { to efficiency-driven }\end{array}$ & $\begin{array}{l}\text { Institutions, macroeconomic, infrastructure, higher } \\
\text { education, market efficiency, and innovation }\end{array}$ \\
\hline 55 & Viet Nam & $\begin{array}{l}\text { Transition from factor-driven } \\
\text { to efficiency-driven }\end{array}$ & $\begin{array}{l}\text { Institutions, macroeconomic, infrastructure, health, } \\
\text { primary education, higher education, market efficiency, } \\
\text { and innovation }\end{array}$ \\
\hline 94 & Cambodia & Factor-driven & $\begin{array}{l}\text { Institutions, macroeconomic, infrastructure, health, } \\
\text { primary education, higher education, market efficiency, } \\
\text { and innovation }\end{array}$ \\
\hline 98 & Lao PDR & Factor-driven & $\begin{array}{l}\text { Institutions, infrastructure, health, primary education, } \\
\text { macroeconomic environment, market efficiency, and } \\
\text { innovation }\end{array}$ \\
\hline
\end{tabular}

Lao PDR = Lao People's Democratic Republic.

Note: Myanmar is not included in the 2017 index report.

Source: World Economic Forum. 2017. The Global Competitiveness Report 2017-2018. Geneva.

Countries belonging to the early stage of PPP policy group also share similarities with these four factors. Lower demand for infrastructure is influenced by population size and its geographical distribution, and purchasing power. It is also shaped by the development stage since it defines the types of infrastructure projects to be prioritized. Some countries are struggling with narrow fiscal capacity, debt management, and macroeconomic stability. They have not yet gained investment grade rating, and their capital market is at a very early stage or does not exist. They have a long way to go to reach PPP-ready systems. Before that, they have to become investment-friendly countries. Therefore, the important step is to improve their investment climate. Referring to the WEF Global Competitiveness Index Report 20172018, the countries in this group occupy the bottom rank among ASEAN member states (Table 4).

The institutions factor is among the main challenges for majority of ASEAN member states. It shows that, apart from having regulations on the table, the capacity to manage is equally important. Policy makers should have sufficient knowledge about markets and investments to be able to design and manage efficient and effective institutional setups. 


\section{A. Risk Management and Support}

Risk management is central in PPP management. Failure in managing risk may lead to large and longterm damages. A critical element of risk management lies on the ability of governments to choose optimum trade-offs among possible schemes to maximize benefits and minimize risks, and assess future risks of the agreed scheme. In many cases, governments tend toward risk-averse choices, leaving the private sector in a risky position that may end the negotiation process. On the other hand, some projects end up with the government bearing excessive liabilities, causing authorities to behave as risk-averse decision makers.

Potential challenging situations may also come from unclear procedures on when the project faces problematic situations and what necessary actions need to be taken. Failed projects do not come in 1 day; there would have been measurable indicators showing the situation. The absence of mitigation monitoring on a regular basis may lead to unawareness of bigger problems.

\section{B. Public-Private Partnerships Compared with Other Funding Options}

While PPP has an increasing role in infrastructure development, there has not been much change over the last decade in terms of its real contribution to overall infrastructure investment. PPP contribution has been stagnant, even in the Philippines, which has a progressive PPP campaign program. Low private sector participation in infrastructure development is not because there is a lack of financiers or contractors in the region, but because of the following classical problems: (i) there is no good pipeline; (ii) ineffective and inefficient legal system; (iii) lack of public sector capacity to assess risk sharing and incentives, and to negotiate; and (iv) lack or absence of supportive financial market. In the end, the public sector may get frustrated in dealing with PPP procedures and decide to choose public funding through the state budget or assign SOEs to take over the project.

In the case of Indonesia, assigning SOEs to develop infrastructure projects has both advantages and disadvantages. The benefits include fast realization, support SOEs' financial leverage, and expected returns from public funds. At the same time, it also has a limitation. It could crowd out private sector participation as there is only a limited fund available for infrastructure investment. SOEs are heavily dependent on public capital placement, given their relatively low capacity to issue bonds or find new equity sponsors. In the absence of market discipline, one should be careful in assessing real returns of SOEs to avoid overoptimism that can create future liabilities. Further, there is the classic problem of soft budget constraint. Executives of SOEs may take moral hazard, knowing that there is no strict penalty for poor performance.

\section{Public-Private Partnerships to Support Master Plan of Association of Southeast Asian Nations Connectivity 2025}

Another expectation from public-private partnership implementation in Southeast Asia is how it can be utilized to support ASEAN Connectivity 2025. Public-private partnership can be used as one possible approach to infrastructure development. The Master Plan for ASEAN Connectivity (MPAC) 2025 proposes five initiatives, namely: sustainable infrastructure, digital innovation, seamless logistics, regulatory excellence, and people mobility (ASEAN 2016). The strategy for sustainable infrastructure initiatives consists of three objectives: (i) increase public and private infrastructure investment in each ASEAN member state, as needed; (ii) significantly enhance the evaluation and sharing of best practices 
on infrastructure productivity in ASEAN; and (iii) increase the deployment of smart urbanization models across ASEAN.

To achieve the first strategy objective, MPAC 2025 proposes Initiative 1, which is to establish a rolling priority pipeline list of potential ASEAN infrastructure projects and sources of funds. It aims to address both the information issues and the capability gaps associated with developing a strong infrastructure pipeline in ASEAN member states. Since its launch in August 2016 and formal adoption by ASEAN leaders in September 2016, there has not been much progress in pushing forward this initiative. Given the complexities of public-private partnership, and the loose relationship between ASEAN member states, it is understandable that there is no strong push to realize this initiative. In terms of the project list, MPAC 2025 is continuing the incomplete projects in MPAC 2010, which consists of 52 projects that fall into the following four strategic areas: ASEAN Highway Network, SingaporeKunming Rail Link, integrated and seamless multimodal transport system, and developed ASEAN Single Aviation Market.

\section{POTENTIALS OF PUBLIC-PRIVATE PARTNERSHIP FOR SOCIAL INFRASTRUCTURE}

Applying the public-private partnership scheme for social infrastructure is relatively new in emerging Southeast Asia and is considered an advanced approach. The focal argument is on utilizing private sector capacity to finance, design, and build, as well as operate the facilities efficiently. Thus, public authorities can reallocate their resources to other functions that cannot be delegated to the private sector. The efficiency arguments are actually valid and strong for public-private partnerships in advanced economies since public-private partnership requires mature policies and implementation. In emerging economies, public-private partnership is typically used to fill some financing gaps in infrastructure demand.

Since public-private partnership is relatively a new concept in Southeast Asia, its application for social infrastructure is still limited. The Philippines has education infrastructure projects (school buildings) built under the public-private partnership framework, while Malaysia has hospital support services. Thailand is still trying to implement public-private partnership in the health sector with support from the Asian Development Bank.

\section{Opportunities and Challenges}

PPP for social infrastructure can take several schemes such as design, build, operate, and maintain the facilities or certain parts of facility; concessions; operations and maintenance; and renovation. The important features are output-based service delivery, private capital takes on some risks from a public entity, and under a long-term contract (covering life cycle). The social infrastructure is typically a medium-sized PPP. Since education and health care are usually local responsibilities, the public agency in charge is the subnational government. This gives some opportunities to develop PPP at the local level.

There are also views that medium-sized PPPs are simpler and, thus, more applicable, which is not always the case. PPP requires a set of complex procedures, including legal actions, technical requirements, intraparty contracts, and many others that will trigger significant costs. The high administrative and legal costs of drafting PPP contracts cannot be justified for the project size under a particular threshold. The proposed solution is to have a "lite PPP," which simplifies PPP procedures 
without losing prudent actions (Zen and Regan 2015). The Philippines' school projects might be the only case study available of a successful social infrastructure PPP.

Malaysia's health service PPP is a bit vague since it is more a partial privatization or management contract rather than a PPP scheme. There is also long delay in the design-buildoperate-maintain PPP projects for the multistory car parks, day care center, pathology laboratory, and blood bank of Sarawak General Hospital. The project was promised in 2003, the request for proposal was announced in 2012, and the tender documents were out in 2013, but it has not yet been executed until now. The failure is not solely because of PPP or social infrastructure factors. As in many other failed projects, it is usually not because of a single cause. In many cases, the capacity of the public agency, including mitigation ability, plays a key role in determining a successful PPP.

\section{PRO-POOR PUBLIC-PRIVATE PARTNERSHIP}

The objective of PPP in public service provision does not differ much from other modalities. Since one of its features is output-based performance, the measures can be very clear and straightforward. On the other hand, traditional public procurements often use several variables that are neither necessary nor sufficient for measurement. For example, the cost of capital from state budget is always considered zero. Thus, opportunity costs of a project are not provided as comparison.

Poverty is a complex issue and it has no single cause. There are many types of vulnerable groups such as minorities, old-age persons, women, children from poor families, and persons with disabilities. Exclusion from public services can drive out people from opportunities to empower themselves. In this context, building infrastructures that are accessible for larger users, including the poor, will make significant changes for them. There are certain types of basic infrastructures essential to fulfill basic human needs and foundations of welfare that can provide opportunities to empower people. Those infrastructures are related to knowledge accumulation, health care, and support for productivity (Figure 4).

Figure 4: Fundamental Infrastructures for Empowering People

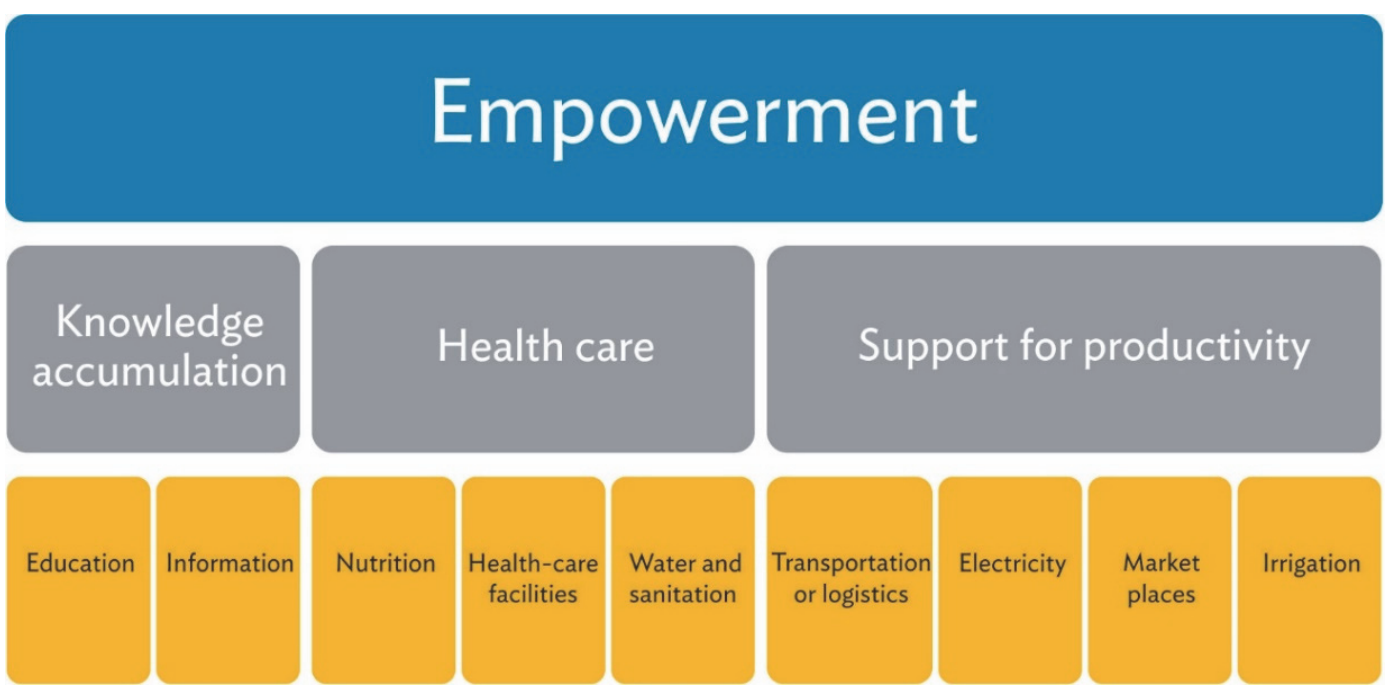

Source: Author. 
ASEAN member states can have pro-growth infrastructures such as the following:

(i) Knowledge accumulation

(a) education: schools, training centers, and research and development facilities;

(b) information: telecommunication, internet, broadcasting, and others that support both formal and informal education.

(ii) Health care

(a) health-care facilities: hospitals, community health centers, information and communication technology for health care;

(b) water and sanitation system;

(iii) Support for productivity

(a) transport: roads, logistics system, seaports, airports, bridges, and railways; seamless connectivity will improve efficiency and reduce high cost economy. Many Southeast Asian countries face geographical challenge in their domestic connectivity, adding the burden to the poor and reducing access to welfare and production facilities.

(b) electricity: renewable and clean energy, micro and small power plants for remote areas; IEA (2017) reports that there are some 65 million people, approximately 10\% of Southeast Asia's population, without access to electricity in the region. In archipelagic countries, such as Indonesia and the Philippines, or in remote areas in the Mekong region, building power supply and its transmission and distribution system are expensive and financially nonviable due to economies of scale. This opens opportunity to have PPPs at small and medium scale off-grid electricity.

(c) market: conventional and financial markets; and

(d) irrigation for farmers and preservation system.

The abovementioned examples are necessary requirements for empowering people, regardless of their social status. It is not a sufficient condition for alleviating poverty. To have impact on poverty reduction, the following are some additional requirements:

(i) accessible to the poor: it is available to be accessed legally (no exclusion),

(ii) affordable: the poor can pay or consume it legally,

(iii) quality standard: reliable services, and

(iv) efficiency: no incentive for overconsumption.

There are no conflicting principles between the PPP system and pro-poor infrastructures. Like other infrastructure projects, pro-poor PPP projects shall fulfill basic principles, such as:

(i) The government must have solid arguments for buying the project. This means the project should return net benefits for the economy. The cost-benefit analysis (CBA) of infrastructure projects should use economic approach instead of financial approach. As long as the socioeconomic CBA turns to be positive, the government still has justification to buy the project, subject to other spending priorities.

(ii) The government contracting agency must have sufficient level of understanding of PPP principles and procedures, especially in legal action, contract management, risk sharing, fiscal support, and negotiation. Technical capacity can be outsourced, if needed.

(iii) Listen to the stakeholders, especially the users. The government contracting agency should understand the real condition and demands of end users. Particularly if the PPP is aimed as a pro-poor project, the government must be sensitive with real demand, purchasing ability, and dynamics of migration. 
A pro-poor program is based on an output or outcome policy. Hence, it does not matter whether the pro-poor project is developed by using traditional procurement or PPP, as long as it can maximize socioeconomic output. Theoretically, a PPP has the advantages of being more public-resource efficient, enforcing market discipline (targeted beneficiaries rather than public subsidy), providing opportunities for knowledge transfer, and enhancing transparency and accountability. For the private sector involved in PPP for pro-poor projects, not only do they receive benefits as socially responsible companies, but they also nurture their market. Better welfare means higher potential to become consumers of private products.

\section{A. Opportunities and Challenges}

Having proper economic CBA can increase transparency, improve understanding and skills, and enhance opportunities for having better mechanisms in choosing project modality. The main challenge of this method is the difficulty of making proper CBA due to constraints in data availability and debatable methodologies. However, the government does not need to make a perfect CBA. A proper CBA is open to public discourse and improves project planning subsequently.

Several social sectors are generally perceived to have larger impact on reducing poverty or improving welfare such as basic and middle education, health care, education-related services, public transportation, water and sanitation, and electricity. Projects that fall under these areas usually have the privilege of receiving minimum objection from stakeholders or the public. Thus, there is a greater chance to have a PPP project that is in line with pro-poor programs.

The United Nations Economic and Social Commission for Asia and the Pacific (2017) wrote the following in its thematic report: "In 2014, approximately 348 million people in the region still lacked access to electricity: a major gap, but a substantial reduction since 2012, when the number was estimated at 426 million. In 2015, 300 million people did not have access to safe drinking water, and 1.5 billion people lacked basic sanitation." The figures have two consequences: if we ignore them, there will be increasing number of unfilled demand and growing poverty; or if we can cover their demand, in the future, the economic demand will increase because poverty reduction creates additional middle-income households that can pay the services at their economic price.

Even though the consequences are clear and rationally all governments will opt for poverty alleviation, it is not an easy undertaking. First, to provide the services to poor households, governments need huge funds. Not only to build the project, but also to provide subsidy to make them able to consume the services at sufficient level. The cost will increase, especially when it tries to reach the unreachable. Second, there are complications in designing funding for the project, including incorporating subsidy in funding schemes, without creating moral hazard or being abused by the nonpoor.

To make PPP projects work, leaders should recognize their importance as additional ways to support poverty alleviation programs. The challenge of having PPPs that are pro-poor is the low purchasing power of end users. This means that the revenue stream cannot rely on user fees without government subsidies. On the other hand, there is limited fund available in the public sector to finance pro-poor programs. Realistically, we can expect that the advantages of PPP such as efficiency, transparency, accountability, and VFM will positively impact the pro-poor programs. However, we cannot expect that many pro-poor projects can use the PPP approach because of budget limitation and its complexities. 


\section{B. Case Studies: Umbulan Water Supply System Project in East Java, Indonesia}

Despite the limitations just discussed, this does not mean that PPPs cannot be pro-poor. The following looks briefly at how one pro-poor PPP project-the Umbulan Water Supply System Project in East Java Province, Indonesia-is built to provide clean water services to the poor at an affordable price. The project is located in a province where only $75 \%$ of the population is served by a water supply system. For the national government, expanding service coverage there was essential to reduce national figures of poverty and inequality.

The Umbulan Project has a long history of development. The initial idea started some 40 years ago, and in 2010 the project was tendered but procured only in 2015. In the beginning of 2016, the Coordinating Minister for Economic Affairs and Chairman of KPPIP led the coordinated efforts, involving Finance Minister, Ministry of Public Works and People's Housing, PT Sarana Multi Infrastruktur (an SOE in infrastructure financing), Province of East Java, and five City and Municipalities. The project is registered as a National Strategic Project and Priority Project.

The project aims to serve 1.3 million people with $93 \mathrm{~km}$ of transmission pipe and was estimated to cost Rp2.05 trillion ( $\$ 143$ million). Local governments and a private consortium are only able to finance $60 \%$ of the project value. Given the project's importance, the national government decided to make this a showcase PPP, and take necessary actions to make the project financially feasible. PT Sarana Multi Infrastruktur, through Project Development Facility, assisted the East Java Provincial Government to prepare and execute the project transactions. Ministry of Finance provided Rp818 billion ( $\$ 57$ million) through viability gap funding scheme to ensure that water can be accessed by the community at affordable tariff.

In December 2016, the project financially closed. The current financial scheme is structured to deliver a bankable and fiscally sound project in accordance with prevailing regulations. Part of East Java Provincial Government's commitment is procurement of approximately 7 hectares of land in the Umbulan water source area in 2017 and will continue to acquire the land for the transmission pipes.

The project concession period is determined for 25 years. The planned construction stage will take about 2 years, thus the project is expected to start operation by mid-2019. Revenue stream comes from user fees. Besides fiscal support from the Ministry of Finance, the Indonesia Infrastructure Guarantee Fund, an SOE providing guarantee for contingent liabilities, also provides guarantee to increase the credit enhancement for the implementing business entity or special purpose vehicle. Figure 5 illustrates the transaction schemes among the actors in the project.

The local public water supply company, Perusahaan Daerah Air Minum (PDAM), currently sells clean water at the price of Rp3,331 per cubic meter $(\$ 0.25)$ but cannot meet the demand. Private suppliers sell clean water at the price of Rp36,000 per cubic meter ( $\$ 2.7$ ) or nearly 11 times PDAM's price. The new price proposal after completion of the Umbulan project is $\$ 0.5$ or about $20 \%$ of current private supply's price. With the new project to service the uncovered poor, the government expects that it will support the welfare and health-care programs.

The Umbulan project shows that coordination under strong leadership can conclude the long delayed process. It also provides an example of the benefits of credit enhancement, provided by the Indonesia Infrastructure Guarantee Fund, and fiscal support through viability gap funding provided by the Ministry of Finance. These schemes are made possible after the government issued Presidential Regulation in 2015, three Minister of Finance regulations, and two Minister of Finance decrees. The 
successful negotiation led by the Coordinating Minister after the project registered as a National Strategic Project and Priority Project of KPPIP also provides the lessons of the importance of commitment and centered decision-making process. And commitment is hard to secure if the number of projects exceeds the capacity to handle, hence it is essential to provide a credible project pipeline. Credible feasibility study assisted by PT Sarana Multi Infrastruktur contributes to the process of structuring appropriate financial scheme to make the project bankable.

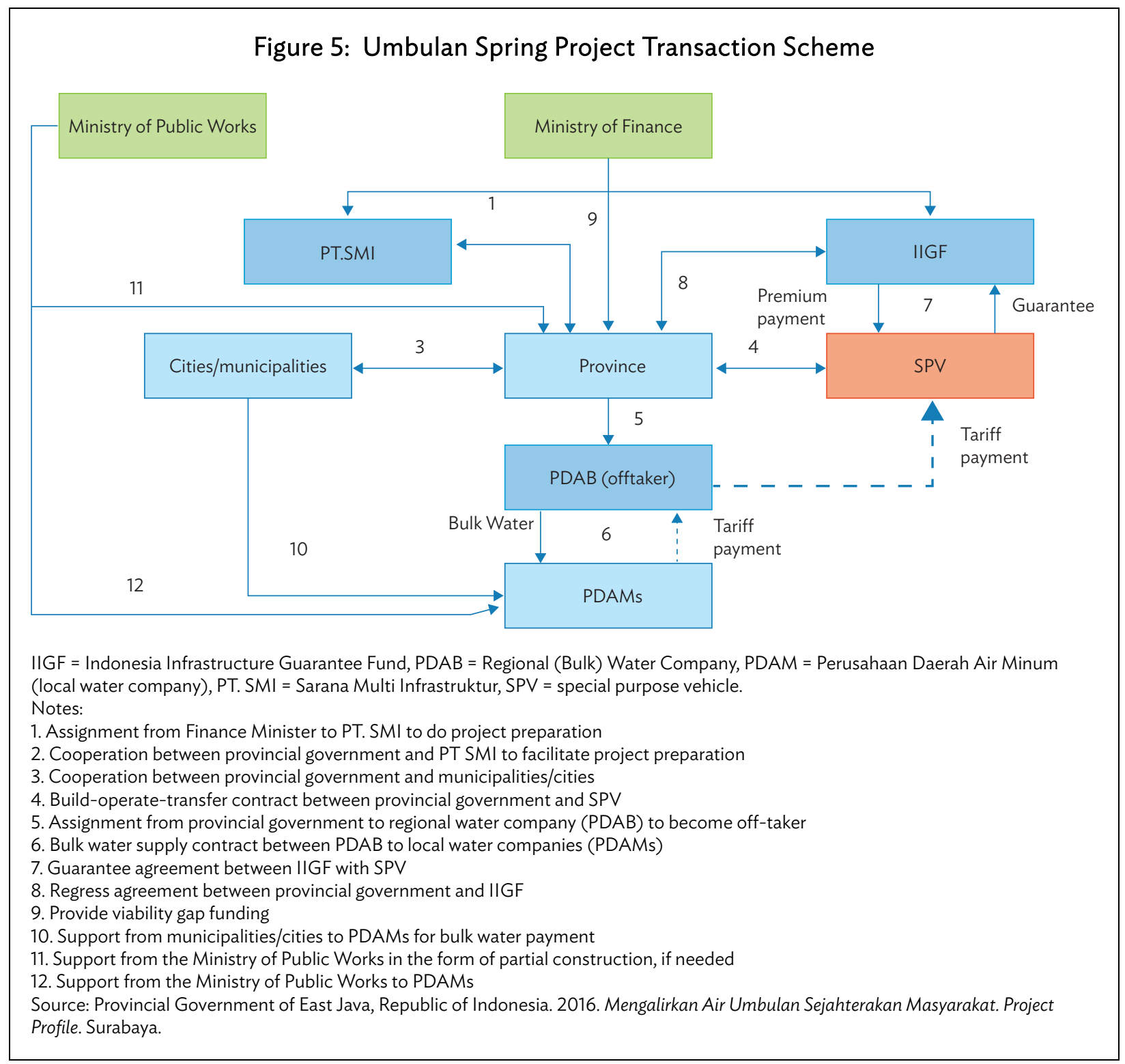




\section{RECOMMENDATIONS}

Although PPP policies across Southeast Asia are at various stages of maturity, the following recommendations to strengthen the policy framework for infrastructure PPPs are offered.

Conducive business environment. Macroeconomic fundamental is vital to attract investment. The countries should strengthen and maintain their macroeconomic stability, fiscal management, sovereign rating, and good governance practice. As the infrastructure industry deals with not only the financial aspects but also the related entities (Figure 4), a good business climate will nurture these components and facilitate efficient markets. This is basic for country development and to become competitive.

Infrastructure financing. PPP is one of the sophisticated financing modalities, which is very different from traditional procurement. It allows bigger participation from the private entity by means of financial structure and engineering, technology and innovation, and risk-sharing schemes. PPP performance is based on service quality and delivery, not on inputs; and contract period is defined by the project life cycle. Consequently, it requires comprehensive understanding and sufficient endowment from the public sector. It also introduces the benefits of market incentives for the public sector. ADB (2017) also emphasized that the PPP feature of risk-sharing creates excellent incentive for the private sector to avoid failure and deliver in a timely and cost-effective manner, high-quality infrastructure and associated services.

Institutions and capacity. Public sector leadership is vital to guide the whole process of PPP. Institutional aspects include legal enforcement, efficient procedures, and effective implementation. All of these require regulatory excellence and expertise from involved public entities. In many cases, it also includes subnational governments and local agencies. In this regard, political economy plays a very important role. The key is to hold vital institutions and strategic officers together to materialize PPP for public benefits.

Project, partner, and process. ADB (2017) summarized the keys of PPP success in these three components. The country shall prepare a suitable and achievable project pipeline, be engaged with a qualified private partner, and institute the right process to ensure that an effective, competitive, and efficient mechanism is in place.

Specific suggestions for tier 1 PPP policy in developing Southeast Asia (Indonesia, Malaysia, the Philippines, and Thailand):

(i) Good planning and timely execution. It is better to come up with a few selected prioritized and well-prepared projects that the government has carefully defined than a long list of several projects intended to attract any type of investor that the government does not actually have the capacity to deal with. Management of deal flow is equally important to make investors know what to expect, and to attract the most ready and matching bidders.

(ii) Technical aspects. Ensure fair risk-sharing vis-à-vis government support, openness to foreign participation, and hiring of prominent experts to represent government's interests.

(iii) Innovative financial schemes. Explore the possibility to improve the value of the project such as using land value capture approach.

(iv) Capacity building. Conduct basic level as well as thematic technical skills training for officers with strategic roles in PPPs at both national and subnational levels. 
Specific suggestions for tier 2 PPP policy in developing Southeast Asia (Cambodia, the Lao PDR, Myanmar, and Viet Nam):

(i) Focus on building good governance and develop options for infrastructure finance. Understand the importance of transparency and accountability, and set the benchmark for other public institutions on this issue.

(ii) List priority projects. Governments should not provide investors with a shopping list. Showing that the government knows its priority will help organize all possible resources to have similar objectives.

(iii) Mobilize and optimize public resources to support infrastructure. Optimize tax revenue and exercise for government and project bonds.

(iv) Capacity building. Focus on the following key issues: good governance, understanding infrastructure industry, and appropriate regulatory framework. 


\section{REFERENCES}

Asian Development Bank (ADB). 2017. Asian Development Outlook 2017 Update Highlights Sustaining Development through Public-Private Partnership. Manila.

Association of Southeast Asian Nations (ASEAN). 2016. Master Plan on ASEAN Connectivity 2025. Jakarta.

Australia Indonesia Partnership for Economic Governance (AIPEG). http://www.aipeg.or.id/.

Government of Malaysia, Prime Minister's Department. 2015. Eleventh Malaysia Plan 2016-2020: Anchoring Growth on People. Putrajaya.

International Energy Agency (IEA). 2017. Southeast Asia Energy Outlook 2017: World Energy Outlook Special Report. Paris: OECD/IEA.

International Monetary Fund (IMF). 2014. World Economic Outlook, October 2914: Legacies, Clouds, Uncertainties. Washington, DC.

IMF, Investment and Capital Stock Dataset. 2017. The Accompanying 2017 Update of the Manual "Estimating Public, Private, and PPP Capital Stocks." http://www.imf.org/external/np/fad/ publicinvestment/data/info122216.pdf and http://www.imf.org/external/pp/longres.aspx?id=4959.

Investor Relations Office. 2017. Philippines Macroeconomic Updates December 2016. Manila.

Ismail, Suhaiza. 2012. "What Drives Value for Money of Public Private Partnership (PPP) Projects Implementation in Malaysia?" Persidangan Kebangsaan Ekonomi Malaysia (PERKEM) 7: 473-83.

Ismail, Suhaiza, and Fatimah A. Haris. 2014. "Constraints in Implementing Public Private Partnership (PPP) in Malaysia." Built Environment Project and Asset Management 4 (3): 238-50.

Lee, Minsoo, Xuehui Han, Raymond Gaspar, and Emmanuel Alano. 2018. "Deriving Macroeconomic Benefits from Public-Private Partnerships in Developing Asia." ADB Economics Working Paper Series No. 551. Manila: Asian Development Bank.

Ministry of Finance, Republic of Indonesia. 2016. "State Budget FY 2016" (in Bahasa Indonesia).

National Development Agency. 2014. "2015-2019 National Development Agenda” (in Bahasa Indonesia).

Nitithanprapas, Ekniti. 2016. "Financing Infrastructure in Thailand." Paper presented at the Second Asia Cooperation Dialogue, Bangkok.

Provincial Government of East Java. Republic of Indonesia. 2016. Mengalirkan Air Umbulan Sejahterakan Masyarakat. Project Profile. Surabaya.

United Nations Economic and Social Commission for Asia and the Pacific. 2017. "Thematic Report: Eradicating poverty and promoting prosperity in a changing Asia-Pacific." Paper presented at the Fourth Asia-Pacific Forum on Sustainable Development, Bangkok. http:/www.unescap.org/ sites/default/files/pre-ds/B1700165_Report\%20No.\%201_E_0.pdf (accessed 17 June 2017). 
24 | References

World Economic Forum. 2016. The Global Competitiveness Report 2016-2017. Geneva.

_ 2017. The Global Competitiveness Report 2017-2018. Geneva.

Zen, Fauziah, and Michael Regan. 2015. Financing ASEAN Connectivity. Indonesia: Economic Research Institute for ASEAN and East Asia. 


\section{Public-Private Partnership Development in Southeast Asia}

This paper provides a landscape of public-private partnership (PPP) infrastructure development in Southeast Asia, where PPP has been promoted as a complement of limited public funds. PPP typically contributes less than $1 \%$ of gross domestic product (GDP), while public finance greatly varies from about $2 \%$ to $10 \%$ of GDP. Among major factors supporting PPP implementation are conducive business environment, good governance, innovative financial schemes, and public sector capacity to manage PPP appropriately. In addition to hard infrastructure development, private participation in social infrastructure is also growing in Southeast Asia.

\section{About the Asian Development Bank}

ADB is committed to achieving a prosperous, inclusive, resilient, and sustainable Asia and the Pacific, while sustaining its efforts to eradicate extreme poverty. Established in 1966, it is owned by 67 members48 from the region. Its main instruments for helping its developing member countries are policy dialogue, loans, equity investments, guarantees, grants, and technical assistance. 